\title{
Evaluation of Foundation Settlement under Various Added Loads in Different Locations of Iraq Using Finite Element
}

\author{
Entidhar Al-Taie1, Nadhir Al-Ansari², Sven Knutsson² \\ ${ }^{1}$ Reconstruction and Projects Department, Minister of Higher Education and Scientific Research, Baghdad, Iraq \\ ${ }^{2}$ Department of Civil, Environment and Natural Resources Engineering, Lulea University of Technology, \\ Lulea, Sweden \\ Email: Entidhar.altaie@ltu.se, nadhir.alansari@ltu.se, Sven.Knutsson@ltu.se
}

Received 14 April 2016; accepted 9 May 2016; published 12 May 2016

Copyright (C) 2016 by authors and Scientific Research Publishing Inc.

This work is licensed under the Creative Commons Attribution International License (CC BY).

http://creativecommons.org/licenses/by/4.0/

(c) (i) Open Access

\section{Abstract}

Settlement is an important criterion in the design of the foundations. It is classifying into immediate (or elastic) settlement and consolidated settlement (primary and secondary). The factors that affect the shallow foundation settlement are the applied loads, soil stiffness, and geometric shape of foundation. Calculations of settlement depend on the parameters of soil which can be obtained from field and laboratory tests. Field and laboratory tests were conducted for twenty three sites in three different regions in Iraq (Mosul, Baghdad, and Basrah). In this research, field and laboratory tests results adopted for two sites from each region depended on the maximum and minimum bearing capacity values. Settlement for each site was calculated using numerical (mathematical) calculations and PLAXIS software under different added loads. The results of settlements beneath the foundation were competing for the sites with maximum value of bearing capacity in Mosul; Baghdad and Basrah. Also, the comparison conducted for sites of minimum bearing capacity value and the results showed different settlement values of each site. The change of settlement values under different loads was linearly in the six sites using numerical (mathematical) calculations. While, the settlement values obtained from PLAXIS software for sites with maximum bearing capacity value showed that Mosul site had the highest value due to the type of soil layers and the difference models of soil used in the software. Basrah site had a settlement value higher than Baghdad site due to the soil layers of sand type only. PLAXIS results for sites with minimum bearing capacity showed that for Basrah site the soil went to failure. While, the settlement values for Mosul and Baghdad sites were close to each other due to have nearly same soil layers. Therefore, high rise buildings could not be used in some sites. Also, soil in some locations and under some added loads needed to be improved before the implementation of any constructions. 


\section{Keywords}

\section{Settlement, Foundation, Field Test, Cohesion Soil, PLAXIS, Consolidation, Over Consolidated Soil}

\section{Introduction}

Settlement is an important criterion in the design of the foundations. Foundation settlement must be estimated carefully to ensure stability of buildings, towers, bridges, and any high cost structures. The main reason for the settlement occurrence is the compressive deformation of the soil. According to [1], settlement is classifying as (Figure 1).

- Immediate (or elastic) settlement: It takes place rapidly after adding loads without any change in the moisture content and volume.

- Consolidation: This type includes two phases:

1) Primary consolidation phase: This phase is a consolidation settlement results from the change of volume due to water extrusion from soil voids. It occurs in saturated cohesive soils and the change happens slow and takes place over a long period of time.

2) Secondary consolidation phase: This phase is compression settlements which consider as a plastic adjustment observe in saturated cohesive soils. It is an extra deformation of soil occurs due to constant adding loads. It follows the primary consolidation phase.

The major factors affect shallow foundation settlements are: applied loads, soil stiffness, width, depth, and shape of foundation [2] [3].

Foundation settlement (immediate, consolidation) are estimated depending on the calculating stresses in the mass of the soil related to foundation pressure. The settlements and stresses distribution and their values are calculating with the assumption that soil model is homogeneous, isotropic, and linearly elastic. They are playing an important role in the foundations design [4].

Immediate settlement usually estimates according to elastic theory, which assumes that the soil may behave elastically under stresses at any point in soil mass. There are usually three types of methods to calculating the elastic settlement [5] [6]:

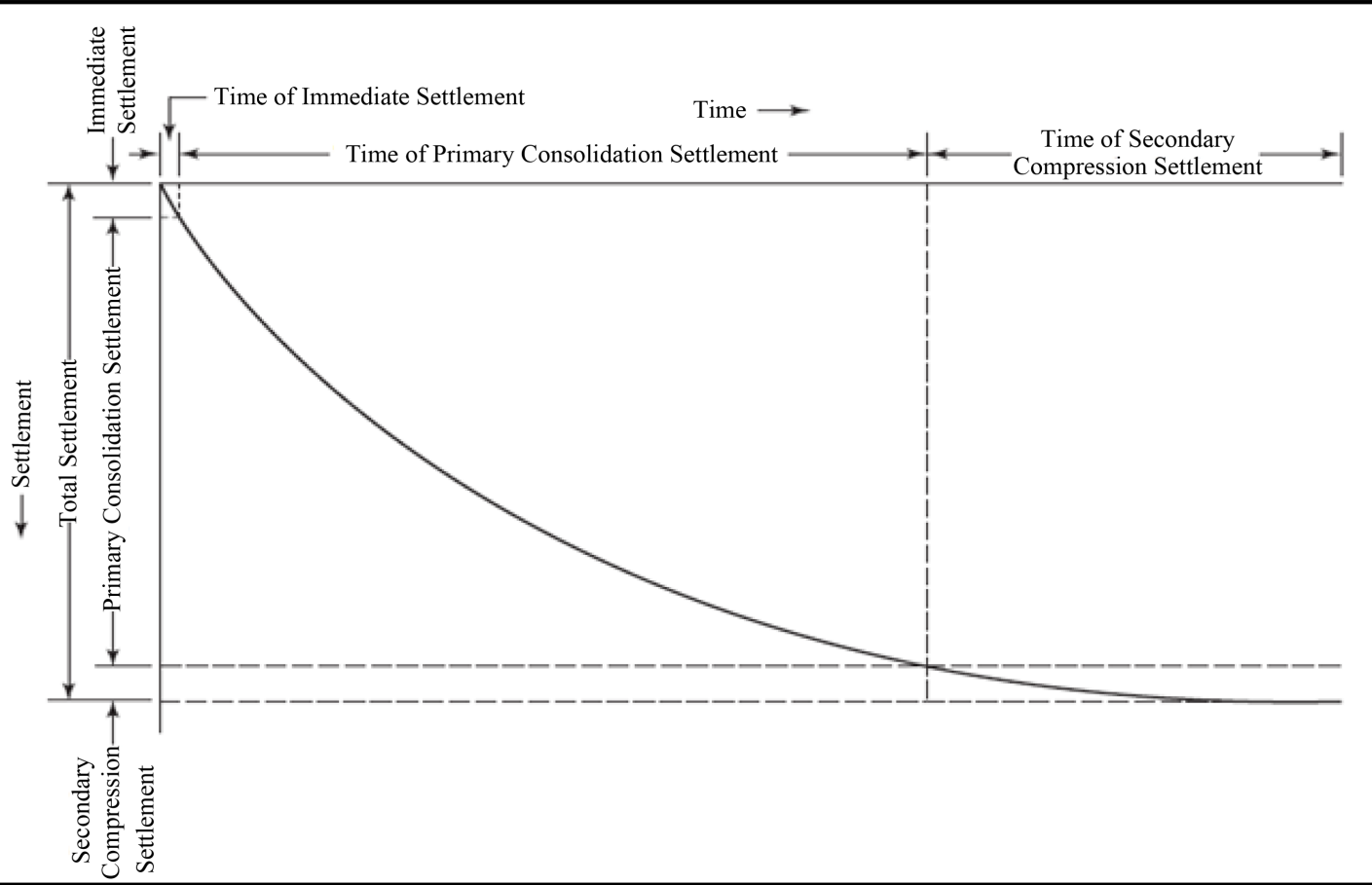

Figure 1.Time-settlement relation (immediate settlement, consolidation, and secondary compression settlement) [1]. 
Empirical methods: They are depending on observation settlement of structure and full scale prototypes. They are depending on correlations of the results from the standard tests in situ such as the cone penetration test (CPT) and the standard penetration test (SPT). Moreover, they contain steps improved by Terzaghi and Peck (1948, 1967), Meyerhof (1956, 1965), DeBeer and Martens (1957), Hough (1969), Peck and Bazaraa (1969), and Burland and Burbidge (1985) [6].

Semi-Empirical methods: They are based on the integration of the theoretical studies and the field observations. The methods contain steps outlined by Schmertmann (1970), Schmertmann et al. (1978), Briaud (2007), and Akbas and Kulhawy (2009) [6].

Theoretical relationship methods: They are relating to the theory of elasticity. The settlement calculations depend on the modulus of elasticity $\left(E_{s}\right)[6]$.

The consolidated settlement is estimating from the consolidation test (Triaxial or oedometer). These tests are the way of estimating the magnitude and time of consolidation to obtain settlement for normally consolidated and over consolidated cohesive soils [1] [7].

The objective of this paper is evaluating shallow foundation settlement under different added loads in three regions of Iraq (Mosul northern, Baghdad central, and Basrah southern parts). The evaluations were conducted using numerical (mathematical) calculations and finite elements (PLAXIS 2D) models. The work was conducted by collecting samples from different sites in the three regions of Iraq. And the behaviour of soil layers is evaluated under the different added loads.

\section{Study Area}

The study areas were located in Mosul northern, Baghdad central, and Basrah southern parts of Iraq (Figure 2) due to the variation in geology and soil formation [8].

- Mosul region situated in the northern part of Iraq. It is occupying part of the foothill zone and north part of Al-Jazira zone (Figure 2). Most of Mosul areas are covering by clay soil, which is moderately to highly expansive type. On the Tigris River banks deposits are result of repeated flooding and the soil consisting of clay, silt and sand. The western part of Mosul region (Al-Jazira) contained soil of gypsum, limestone and sandstone types. The ground water table depth in Mosul region is about $20 \mathrm{~m}$ but in some places it is about

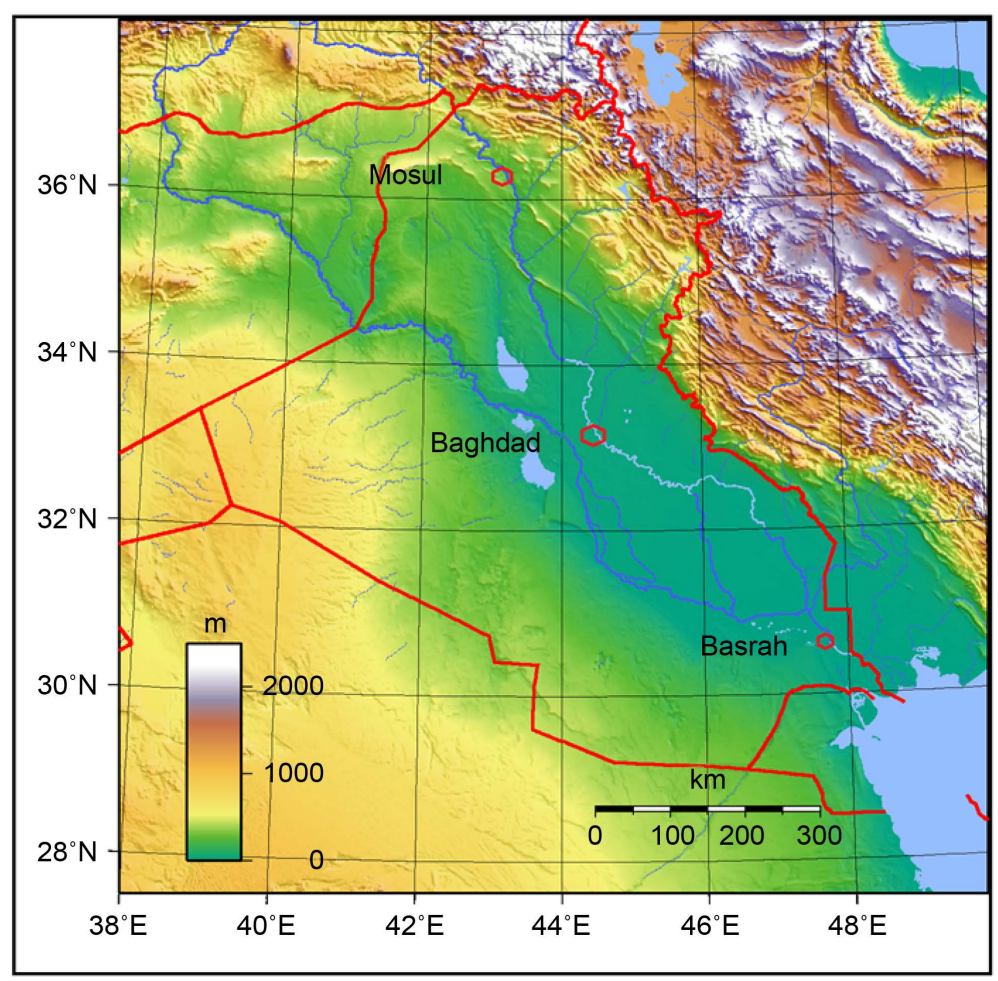

Figure 2. Map of the locations of the study area in Iraq. 
3 m depth [8] [9].

- Baghdad region is the capital of Iraq, situated in the upper part of Mesopotamian plain (Figure 2). Quaternary sediments cover the area; these sediments are accumulating as result of the recurrence of the two rivers floods. Soils of Baghdad are of silty clay and silt loam with low salinity. A fine sandy and silty type of soil deposited along the streams. The depth of ground water in Baghdad region is between 1 to $10 \mathrm{~m}$ [10] [11].

- Basrah region situated in the lower part of Mesopotamian plain southern of Iraq. The sediments of this plain are related to the Quaternary period. Multi-sources of sediments have been classified as fluvial, deltaic and marine. These sediments are of economic value because they used in constructions. Most of the sediments of fluvial type and composed of sand, silt and clay. Tigris and Euphrates Rivers were the main sources of these sediments, also contain carbonates and gypsum grains. The ground water table in Basrah region is less than 1 $\mathrm{m}$ to less than $5 \mathrm{~m}$ [12] [13].

\section{Methodology}

\subsection{Soil Investigations}

Samples were taking from the three regions of Iraq (Mosul, Baghdad, and Basrah). Boreholes drilled to different depth ranges between $3 \mathrm{~m}$ to $24 \mathrm{~m}$ depend on depth of dense soil layers, to obtained disturbed and undisturbed samples from all sites. Table 1 showed that the number, the depth and the location for each sample from six sites were selected and had been used in this research.

\subsection{Laboratory Tests}

Different types of tests conducted for these samples to define the soil classification and mechanical properties. The tests were: physical test, index properties (Atterberg limits and grain size), shear strength test (direct shear and unconfined compression), and oedometer test. Two sites selected from each region (Mosul, Baghdad, and Basrah) depended on the bearing capacity value (maximum and minimum) obtained from the field and laboratory tests [11].

\subsection{Computations of Settlements}

Computations of soil settlement under different added loads for the three regions of Iraq conducted and explained in the following sections:

\subsubsection{Numerical (Mathematical) Calculations}

The analytical calculations were conducted based on the oedometer tests for cohesion soil layers. While, for cohesionless soil layers the immediate settlement calculations were conducted based on the SPT field tests:

1) The calculations of consolidated settlement were depending on a plot of the void ratio (e) against (log scale) effective pressure $\left(\sigma^{\prime}\right)$, which is obtaining from oedometer test [5] [14]. The results of these tests are shown in Figures 3-5.

From curves shown in Figures 3-5: the compression index $C_{c}$, swelling index $C_{s}$, and void ratio $e$ values were obtaining. Boussinesq equation used to determine the effective stress at the corner of rectangular foundation $\Delta \sigma^{\prime}$ $(\mathrm{KPa})$ for the different layers of soil mass of $75 \mathrm{~m}$ depth. The following equation used to calculate the normal

Table 1. Location, number and depth of samples in the three regions.

\begin{tabular}{cccc}
\hline Region & Location & No. of samples & Depth (m) \\
\hline \multirow{2}{*}{ Mosul } & Al-Hamedat & 3 & $1,2,3$ \\
& Al-Rashidia & 3 & $1,2,4$ \\
\multirow{3}{*}{ Baghdad } & Al-Karada & 4 & $2,4,8,13$ \\
& Al-Jadrea & 4 & $2,4,8,13$ \\
\multirow{2}{*}{ Basrah } & Al-Rumaila & 3 & $1,5,10$ \\
& Al-Hartha & 4 & $2,6,13,24$ \\
\hline
\end{tabular}




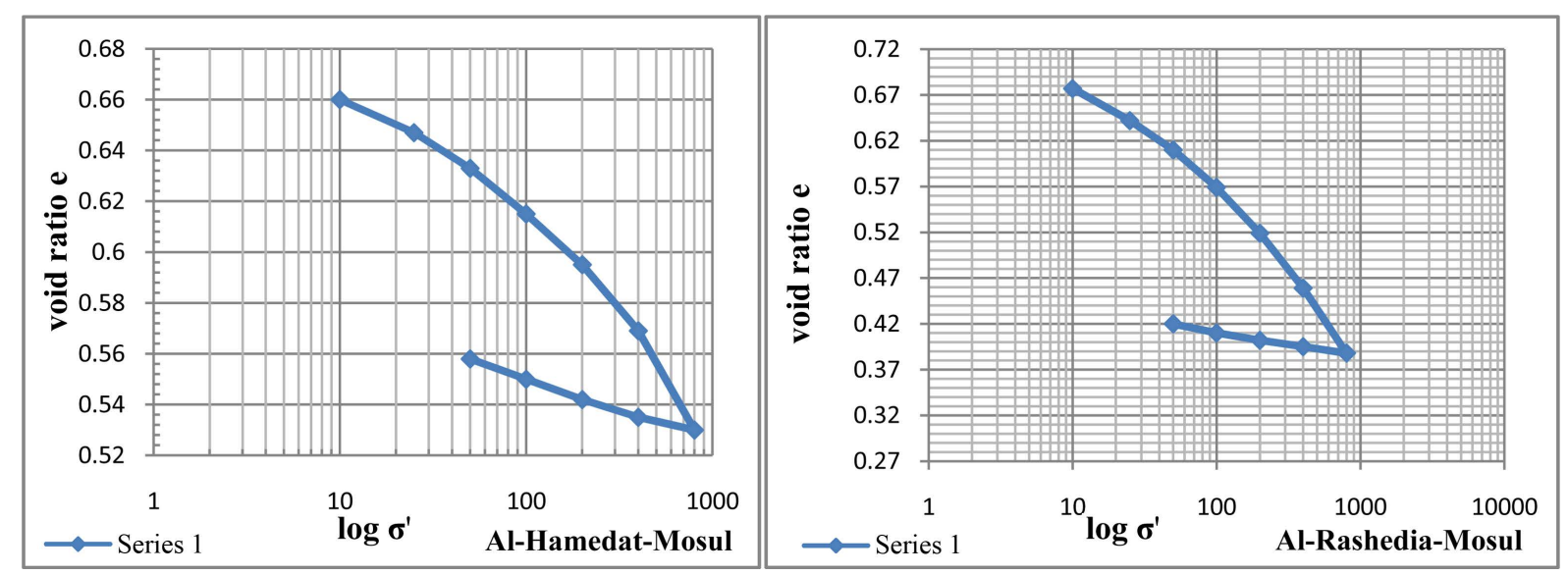

Figure 3. Plot of void ratio (e) vs. effective pressure $\left(\sigma^{\prime}\right)$ for Mosul sites.

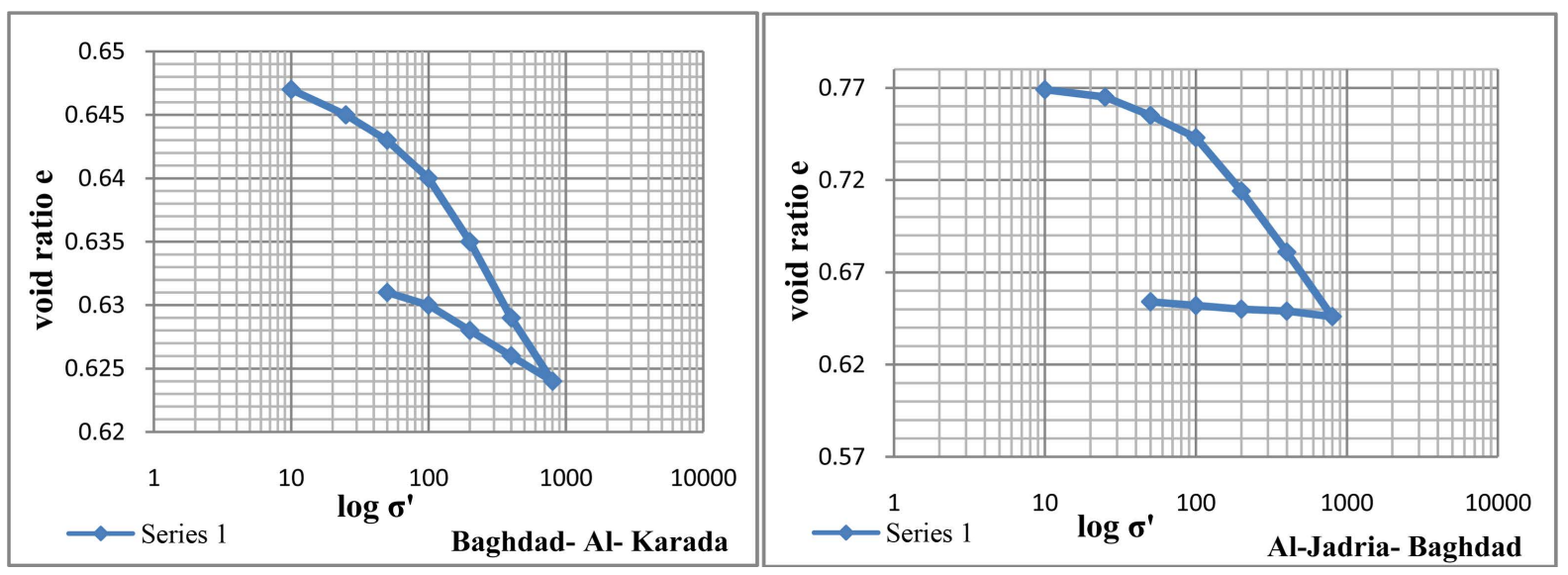

Figure 4. Plot of void ratio (e) vs. effective pressure $\left(\sigma^{\prime}\right)$ for Baghdad sites.

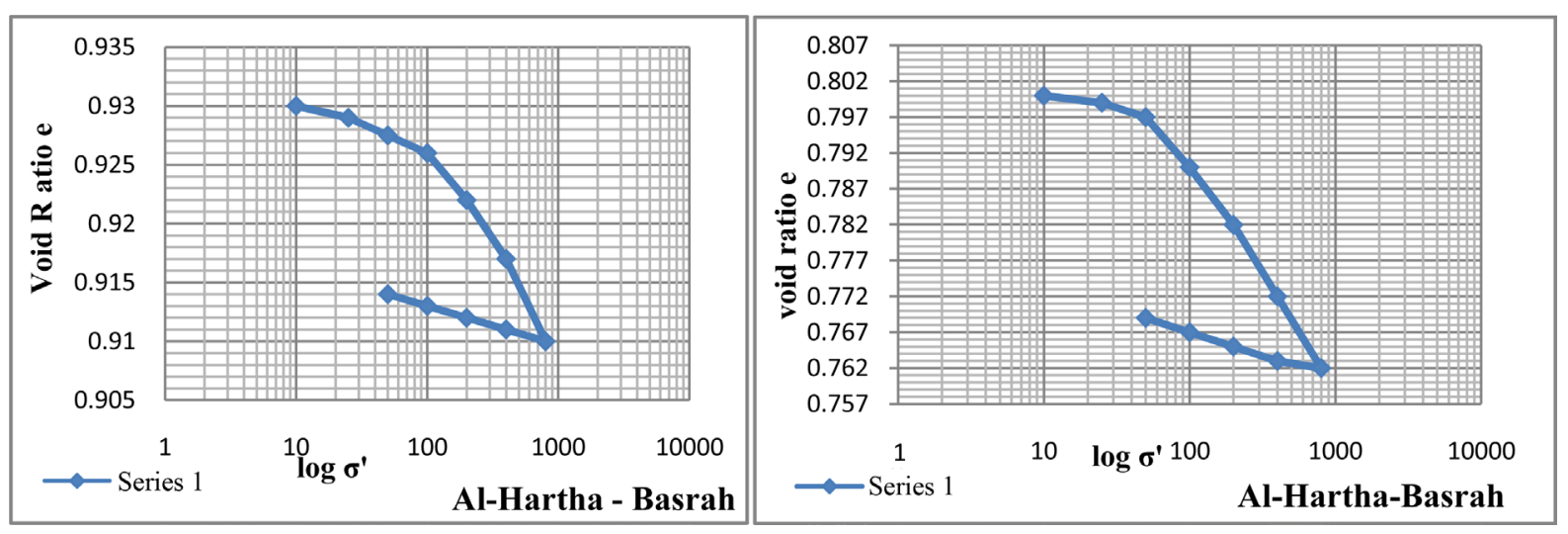

Figure 5. Plot of void ratio (e) vs. effective pressure $\left(\sigma^{\prime}\right)$ for Basrah site.

consolidated cohesion soil [1]:

$$
S_{c}=\frac{C_{c}}{1+e_{o}} H \log \left(\frac{\sigma_{o}^{\prime}+\Delta \sigma^{\prime}}{\sigma_{o}^{\prime}}\right) .
$$

where: $S_{c}=$ consolidated settlement $(\mathrm{mm})$.

$H=$ thickness of soil layer (m). 
For overconsolidated cohesion soil the following equations used [1]:

$$
\begin{gathered}
S_{c}=\frac{C_{s}}{1+e_{o}} H \log \left(\frac{\sigma_{o}^{\prime}+\Delta \sigma^{\prime}}{\sigma_{o}^{\prime}}\right) \text { for } \sigma_{o}^{\prime}+\Delta \sigma^{\prime} \leq \sigma_{c}^{\prime} \\
S_{c}=\frac{C_{s} H}{1+e_{o}} \log \frac{\sigma_{c}^{\prime}}{\sigma_{o}^{\prime}}+\frac{C_{c} H}{1+e_{o}} \log \left(\frac{\sigma_{o}^{\prime}+\Delta \sigma^{\prime}}{\sigma_{c}^{\prime}}\right) \quad \text { for } \sigma_{o}^{\prime}+\Delta \sigma^{\prime}>\sigma_{c}^{\prime}
\end{gathered}
$$

2) The immediate or elastic settlement for cohesionless soil layers carried out using the following formula which depends on Standard Penetration Test (SPT). This test was performed in the fields. The calculations assumed that the foundation is flexible [2] [15] [16]:

$$
S_{e}=q_{o} B \frac{1-\mu^{\prime}}{E_{s}} I_{s}
$$

where: $S_{e}=$ immediate settlement for flexible foundation (mm).

$\mu^{\prime}=$ Poisson's ratio.

$I_{s}=$ influence factor.

$B=$ width of foundation (m).

$q_{o}=$ applied pressure $(\mathrm{kPa})$.

$E_{s}=$ Young's Modulus of Elasticity $(\mathrm{kPa})$.

The immediate settlement of a rigid foundation estimated according to the following formula [2]:

$$
S_{e(\text { rigid })}=0.93 S_{e(\text { flexible })}
$$

The Young's modulus of elasticity of soil obtained from the following equation [2]:

$$
E_{s}=500(N+15)
$$

where: $N=$ the value of blows of SPT test.

The influence factor calculated from the following formula:

$$
I_{s}=I_{1}+\left(\frac{1-2 \mu^{\prime}}{1-\mu^{\prime}}\right) I_{2}
$$

where: $I_{1}=L / B=m$, and $I_{2}=H / B=n$ and $m, n$ can be estimated from tables [2].

Poisson ratio of soil $\left(\mu^{\prime}\right)$ calculated according to the following relation [15]:

$$
\mu^{\prime}=\frac{1-\sin \varnothing}{2-\sin \varnothing}
$$

All the calculations were done for the six sites under different loads of values 56; 63.5; 68 ; 75 and $93 \mathrm{kPa}$. Theses loads present the dead and live load for buildings with two, three and four stories, respectively.

\subsubsection{PLAXIS Modelling}

The finite element method is the most used method for analysis in engineering works. PLAXIS 2D software is a finite element tool which is used for geotechnical works. In view of the fact that soil is a material behaves differently under loading, unloading and reloading [17] [18]. PLAXIS 2D software used in this research to simulate the soil behaviour under raft foundation for different sites and loads. The finite element soil geometry model adopted for the analysis of raft foundation of $(25 \times 60) \mathrm{m}$, and the added loads (dead and live loads) used were 56; 63.5; 68; 75 and $93 \mathrm{kPa}$. The same foundation and loads used for the six sites in the three Iraqi regions (Mosul, Baghdad and Basrah) with different soil conditions. The soil models used in the software were Harding soil (HS) for the cohesion soil and Mohr-Coulomb (MC) model for cohesionless soil. The parameters that were used for the soil models in the software for each site were obtained from the field and laboratory tests as shown in Table 2. After the creation of the geometry of the two-dimensional (2D) model the mesh were generated automatically [19].

\section{Results and Discussions}

Estimation of settlement under foundation for different loads conducted using numerical (mathematical) calculations and PLAXIS software. The equation used in the numerical calculation was the Boussinesq equation for the 
Table 2. Soil parameters used for the two models at different locations.

\begin{tabular}{ccccccc}
\hline Soil parameters & \multicolumn{2}{c}{$\begin{array}{c}\text { Mosul Region } \\
\text { Hamedat Rashidia }\end{array}$} & \multicolumn{2}{c}{$\begin{array}{c}\text { Baghdad Region } \\
\text { Karada Jadrea }\end{array}$} & $\begin{array}{c}\text { Basrah Region } \\
\text { Rumaila Hartha }\end{array}$ \\
\hline Material model & HS & HS \& MC & HS \& MC & HS \& MC & MC & HS \& MC \\
Unsaturated weight $\left(\gamma_{\text {unsat }}\right), \mathrm{kN} / \mathrm{m}^{3}$ & 19 & 19,20 & $20,21,19$ & 18 & $17.55,18.7,19.66$ & $18.6,19,19$ \\
Saturated weight $\left(\gamma_{\text {sat }}\right), \mathrm{kN} / \mathrm{m}^{3}$ & 20 & 23,24 & $20,21,19$ & 19,20 & $17.55,18.7,19.66$ & $23,23.4,25$ \\
Compression index $\left(\mathrm{C}_{\mathrm{c}}\right)$ & 0.126 & 0.21 & 0.01560 .109 & 0.108 & - & $0.191,0.224$ \\
Swelling index $\left(\mathrm{C}_{\mathrm{s}}\right)$ & 0.019 & 0.022 & 0.0540 .027 & 0.0067 & - & $0.029,0.027$ \\
Initial void ratio $(\mathrm{e})$ & 0.650 & 0.677 & 0.6470 .455 & 0.741 & - & $0.8,0.93$ \\
Modulus of elasticity $(\mathrm{E}), \mathrm{kN} / \mathrm{m}^{2}$ & - & 32,500 & 32,167 & 32,500 & $26,83332,500$ & 32,500 \\
Passion's ratio $\left(\mu^{\prime}\right)$ & - & 0.35 & 0.35 & 0.37 & $0.31,0.28,0.26$ & 0.36 \\
Cohesion $(\mathrm{C}), \mathrm{kN} / \mathrm{m}^{2}$ & 40 & 0 & 185.3 & 38 & $4,2,0$ & 12 \\
Friction angle $\left(\phi^{\circ}\right)$ & 20 & 28 & - & - & $33,38,41$ & 26 \\
Dilatancy angle $\left(\psi^{\circ}\right)$ & - & - & - & - & $3,8,11$ & 0 \\
\hline
\end{tabular}

purpose of the calculated settlement in each layer of soil. Equations (1)-(3) used to calculate the consolidation settlements for cohesion soil layers. The immediate settlement was calculated using Equations (4)-(8) for cohesionless soil layers. The Hardening Soil (HS) model was used in PLAXIS for cohesion soil layers. And MohrCoulomb (MC) model was used for the cohesionless soil layers. All the results were obtained from the two methods as following:

\subsection{Numerical (Mathematical) Results}

The results obtained from numerical calculations were performed by dividing mass of soil into layers. The data depended on the field and laboratory tests and the groundwater level was taking into consideration through the calculations of $\sigma_{o}^{\prime}$ for each layer. The numerical calculations conducted for the mass of soil with $75 \mathrm{~m}$ depth in all sites. The settlement values obtained from numerical calculations showed that the settlement increased linearly. Also, it was related to the bearing capacity value of each site. The results of the calculated settlement for the six sites were shown in Figure 6 and Figure 7. The results shown in Figure 6 for the sites with maximum bearing capacity value, the settlement values for Al-Rumaila-Basrah were less than the other two sites due to the soil of sand and the all values of settlement were less than the limits of EC standards (25 mm for isolated shallow foundation and $50 \mathrm{~mm}$ for raft foundation [20]. Al-Hamedat-Mosul the values of settlement were higher than the other two sites due to the soil of clay of medium plasticity. The settlement values under the four added loads were less than the limits of EC standards. While, the last settlement value was higher than the standard limits, which mean that this site is suitable for normal building with not more than three stories. Also soil layers need improvement under high added loads. While for Baghdad and Basrah sites are suitable for buildings with four stories.

The results shown in Figure 7 were for the sites with minimum bearing capacity value. For Al-Hartha site (Basrah) had the highest settlement values due to the loose layer of soil (soft sandy silt to medium silty sand). While for the two sites Al-Rashidia and Al-Jadrea (Mosul and Baghdad, respectively) the settlement values were close to each other due to the both sites included soil layers of nearly same type (silty clay, clayey silty sand, sand) and they sited on the bank of Tigris River.

\subsection{PLAXIS Results}

The same soil properties and type of foundation used in the numerical calculations also used for PLAXIS model. The data used in the programme shown in Table 2. PLAXIS software used to obtain the values of settlement in each site under different added loads (56; 63.5; 68; 75 and 93) $\mathrm{kPa}$. The settlement calculations conducted for different types of soil layers in the different sites under the raft foundation. 


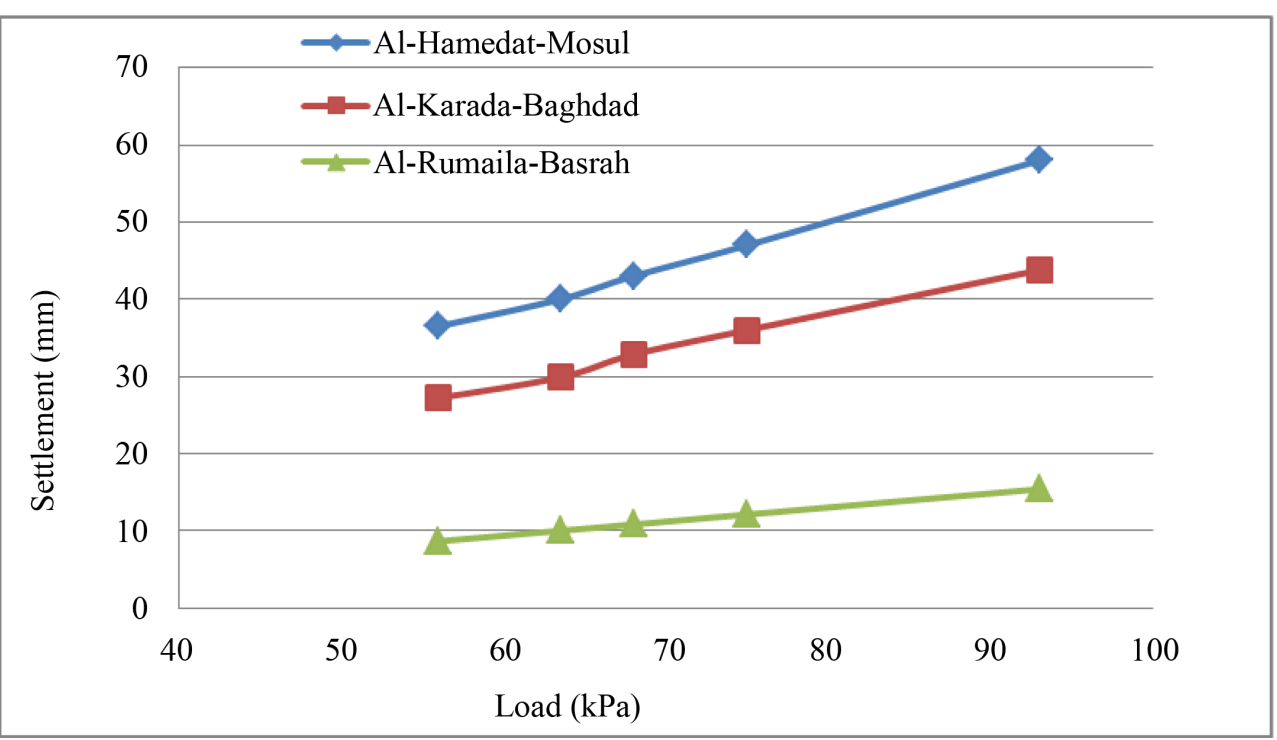

Figure 6. Settlement obtained from numerical calculations for sites with maximum bearing capacity value for the three regions.

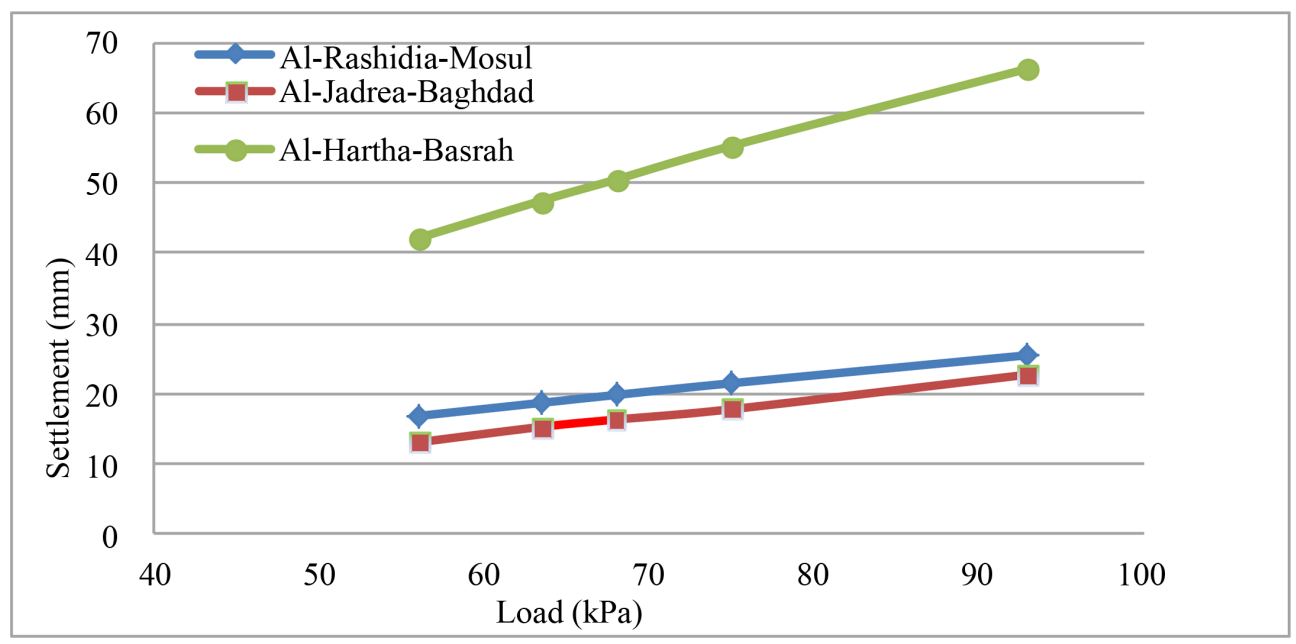

Figure 7. Settlement obtained from numerical calculations for sites with minimum bearing capacity value for the three regions.

Figure 8 shows results obtained from PLAXIS software for Al-Hamedat and Al-Rashidia sites of Mosul region. The settlement values for Al-Hamedat (maximum bearing capacity) were less than settlement values for Al-Rashidia (minimum bearing capacity). The last value of settlement increased not linearly at Al-Hamedat which main that soil could not hold that amount of load and highly compressed. For Al-Rashidia the settlement value was linearly increase.

Figure 9 illustrated the results extracted from PLAXIS software for Al-Krada and Al-Jadrea sites in Baghdad region. The settlement values for Al-Krada were less due to the high value of bearing capacity. Al-Jadrea site had high settlement values due the low value of bearing capacity. Results were increasing linearly.

Whilst, the results obtained from PLAXIS software for Basrah region (Al-Rumaila and Al-Hartha) illustrated in Figure 10. The settlement values for Al-Rumaila site increased linearly with low values due to the type of soil layers of sand only and the high bearing capacity value. The settlement values for Al-Hartha site showed very high values and the soil finally go to failure. The reason for that is the loose of soil layers and low value of bearing capacity.

All the sites in the three regions were consisting of soil layers of cohesion and cohesionless type except two 


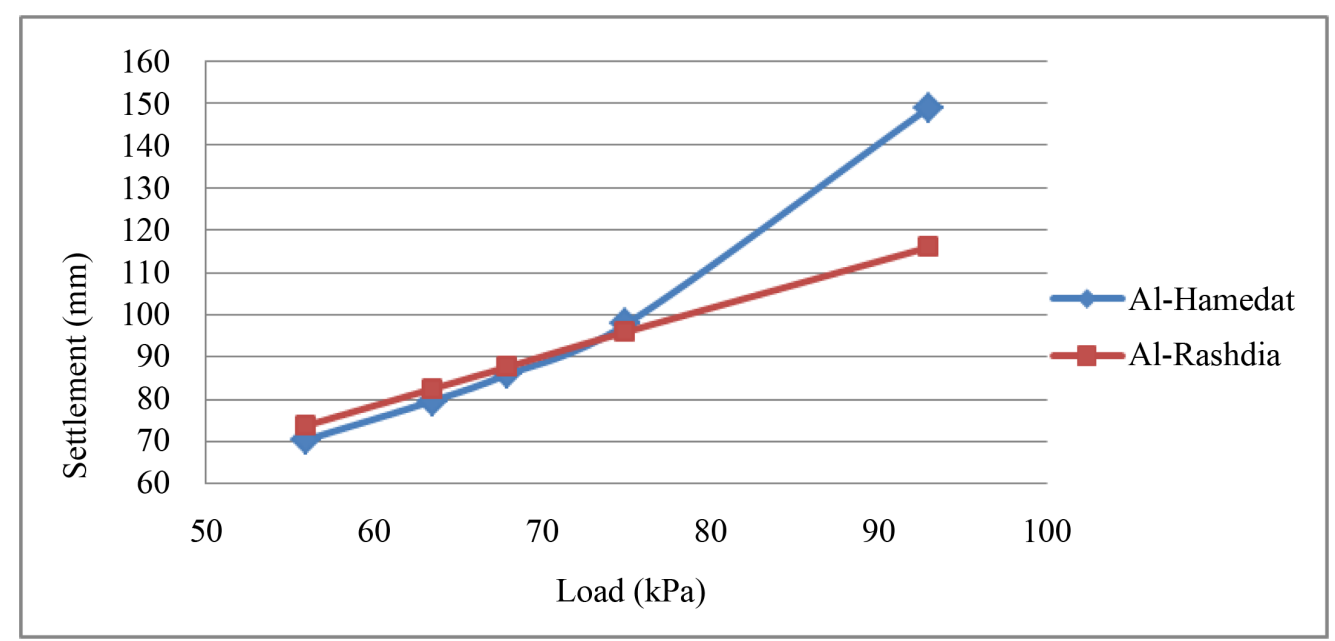

Figure 8. Settlement values for Al-Hamedat and Al-Rashidia sites in Mosul region.

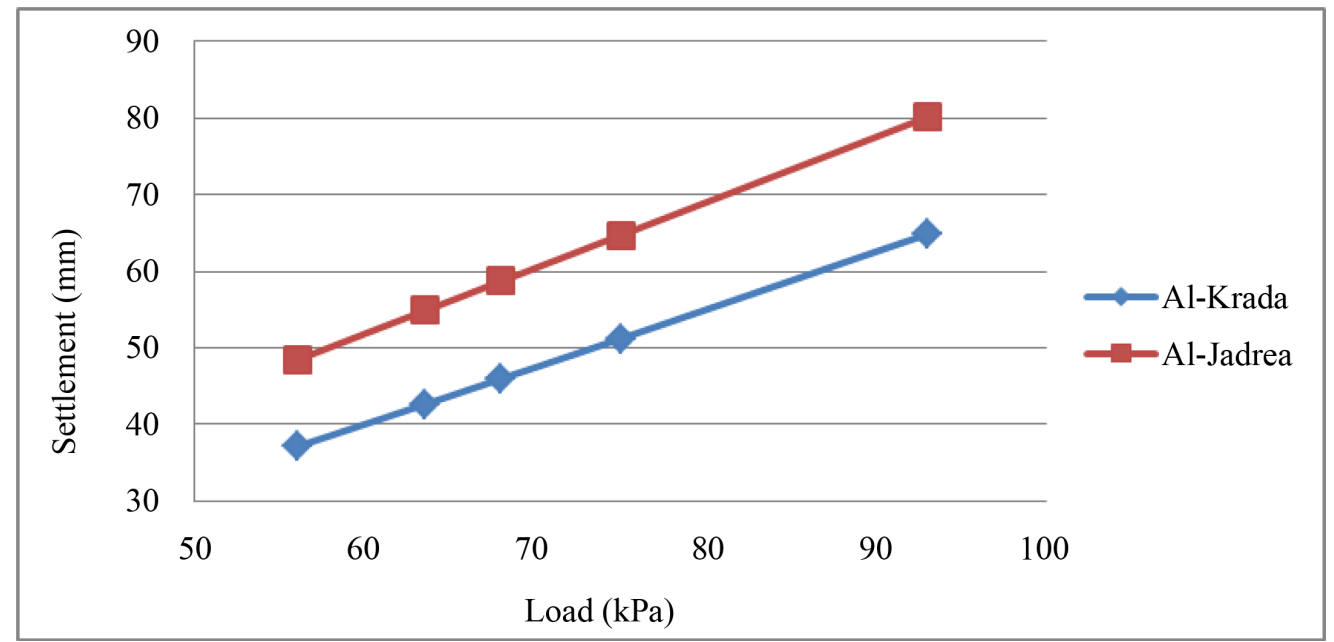

Figure 9. Settlement values for Al-Karada and Al-Jadrea sites in Baghdad region.

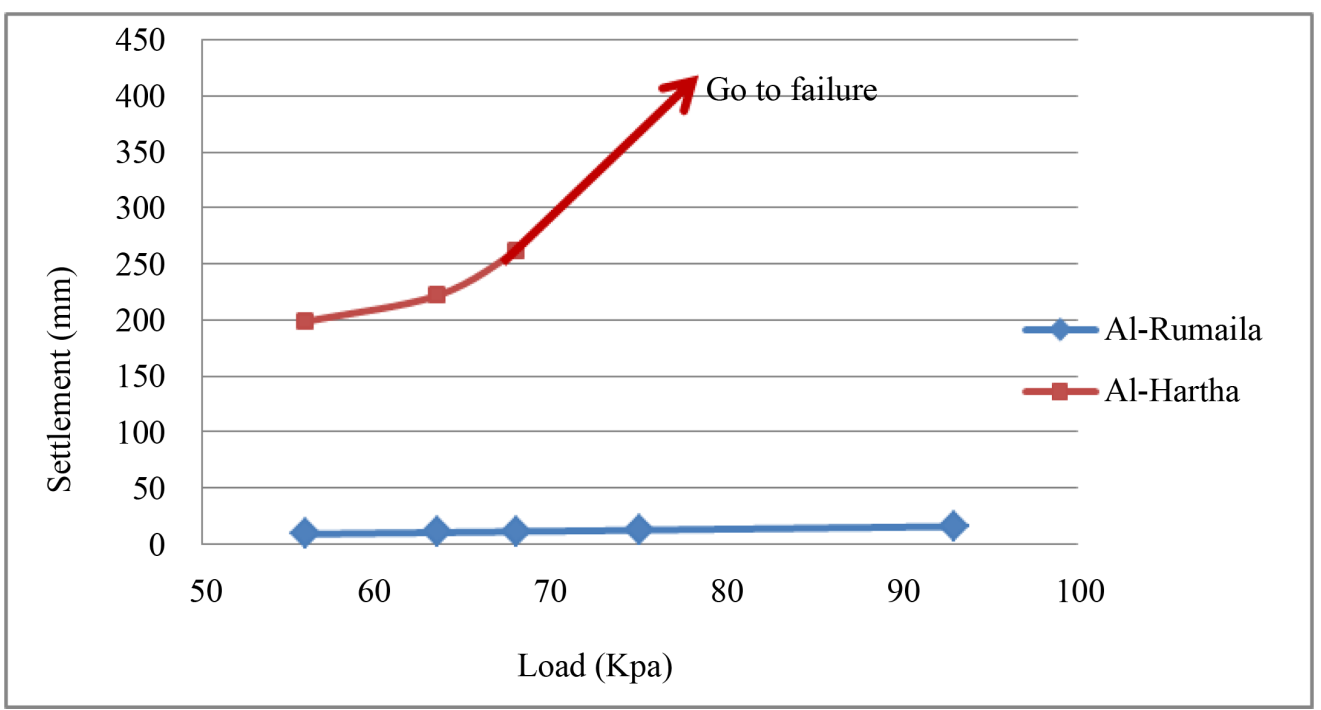

Figure 10. Settlement values for Al-Rumaila and Al-Hartha site in Basra region. 
sites. Al-Hamedat (Mosul region) which was completely consisting of cohesion soil (brown clay) and Al-Rumaila (Basrah region) was completely consisting of cohesionless soil (sand). Also, the differences in layers of the soil obtained various behaviours under the added loads.

The results obtained from the PLAXIS software were depended on the elastic-plastic behaviour of the soil layers under different added loads. The level of groundwater was stated in the model of each site. Soil parameters which obtained from the experimental tests (field and laboratory) used in the software. The settlement values were affected according to the water content and grain size of the soil that is change depending on the geology and climatic of the locations. The models of soil used in the software were: Hardening soil (HS) and Mohr Coulomb (MC). HS model depends on the stiffness parameter of the soil obtained from the oedometer tests. MC model depends mainly on the elastic parameters are the Modulus of elasticity and the Poison's ratio of the soil. The results presented in Figure 8 show differences in the settlement for the both sites in Mosul region under different added loads due to the different types of soil layers (clay only and silty clay, sand). Figure 9 the results were parallel to each other related to the similarity of soil layers types (silty clay, silty sand, sandy silt and sand). For Basrah sites the results shown in Figure 10 were different also due to the soil layers types which is for the lower line the soil type was only sand. The other site was containing silty clay, silty sand and sand of loose soil layers and they collapsed under heavy loads.

Figure 11 and Figure 12 showed the comparison between the settlement values obtained from PLAXIS

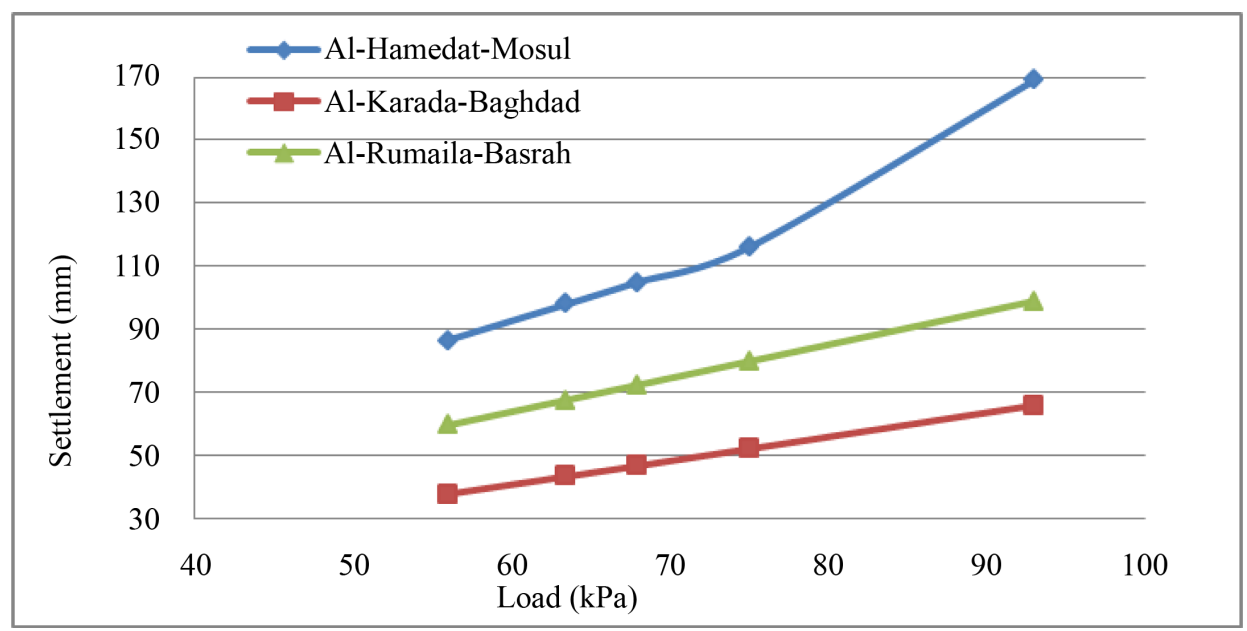

Figure 11. Comparison for PLAXIS results for the maximum bearing capacity values in the three regions.

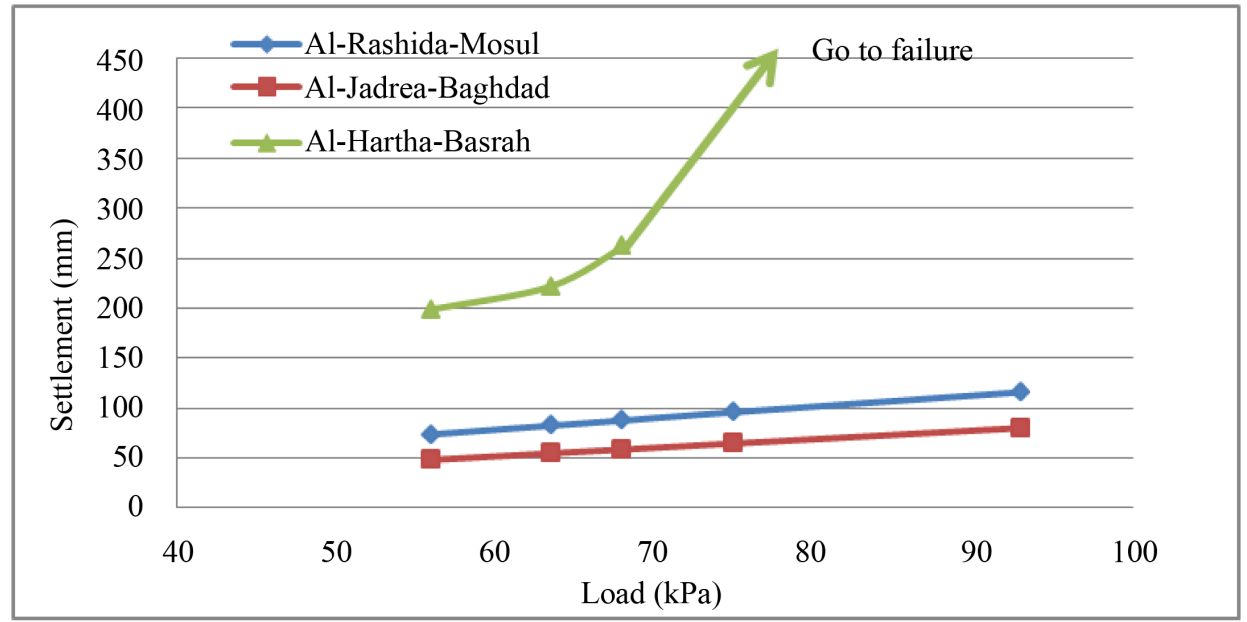

Figure 12. Comparison for PLAXIS results for the minimum bearing capacity values in the three regions. 
software for the different sites in the three regions. The comparison show that the values of settlements in Figure 11 for Mosul site is the highest value due to the soil model used (HS) and the layers of clay type with high compressibility. Whilst, Basrah site has a settlement value higher than Baghdad site due to the soil model used (MC) and layers of sand type only. For Baghdad site the soil model used of both HS and MC.

Figure 12 showed the compressibility of soil for Mosul and Baghdad sites are very close to each other due to nearly same soil layers type (silty clay, clayey silty sand, sand) and to their position near the bank of Tigris River. For Basrah site the compressibility of soil very high and the soil has high settlement value and it goes to failure due to the loose layers of the soil and low bearing capacity value.

The results obtained from PLAXIS were higher than vales obtained from mathematical calculations for all sites in the three regions for different reasons such as the difference of the soil models used for the different sites HS and MC. For some sites, both HS and MC models were used. While, for other sites used only HS model or only MC models. Figure 13 showed the comparison behaviour of the soil models in software with the real response of soil. The curves show that the behaviour of MC model is linear; while the HS model behaves nonlinearly which is nearly similar to the behaviour of the real soil [21]. Also the mathematical calculations were done linearly not as in the software conducted along the curves show the real behaviour of soil layers.

\section{Conclusion}

Numerical (mathematical) and finite element (PLAXIS) methods are means depending on the field and the laboratory tests. They used to estimate the settlement values beneath foundation for different added loads. The results obtained from the numerical (mathematical) calculations for the six sites in the three regions and under different loads were increases linearly. The difference of settlement values was depending on the soil layers types, water table depth and bearing capacity values. PLAXIS models were an approximation of the reality. The results obtained from PLAXIS software showed the approximate real behaviour for the soil under different loads. The software was using soil parameters of stiffness and strength, depending on the elastic theory and clarified the elastic-plastic behaviour of the soil layers. PLAXIS results were explaining that soil in some sites of the three regions needed to be improved before implementation of any buildings. Finally, the numerical (mathematical) calculations for the settlement values showed that some sites were not suitable for high rise buildings. Whilst, PLAXIS software results of settlement values under different loads were not linearly for some sites depending on the layers type and compressibility of soil and ground water level. Also, it shows almost the realistic

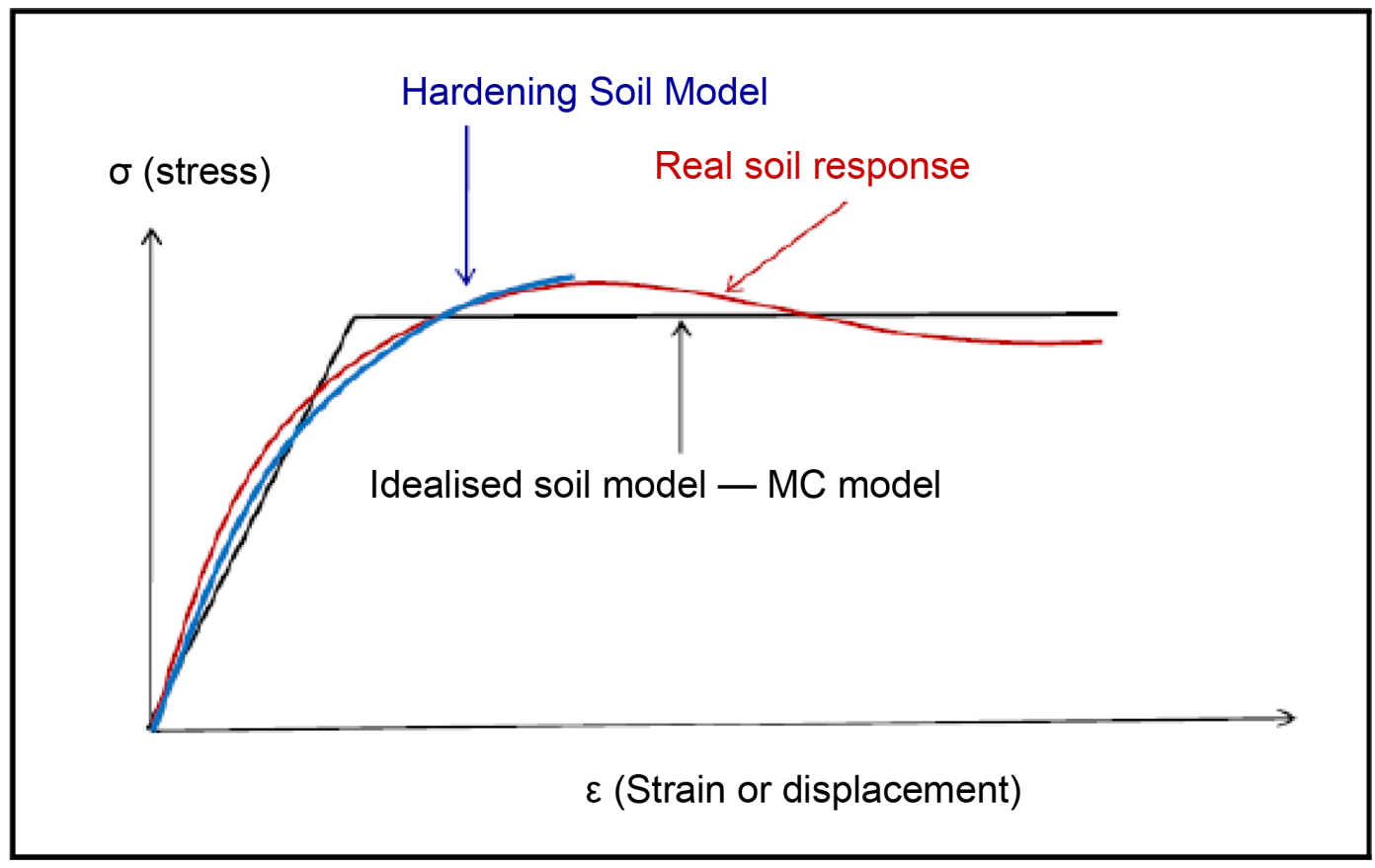

Figure 13. HS, MC and real soil response comparisons [21]. 
behaviour of the soil under load. PLAXIS software is a good tool which must be used to explain the deformation and soil behaviour under different loads.

\section{References}

[1] Liu, C. and Evett, J.B. (2008) Soils and Foundations. 7th Edition, Pearson Prentice Hall, Upper Saddle River.

[2] Bowles, J.E. (1996) Foundation Analysis and Design. 5th Edition, The McGraw-Hill Companies, Inc., New York.

[3] Shahriar, M.A., Sivakugan, N., Urquhart, A., Tapiolas M. and Das, B.M. (2013) A Study on the Influence of Ground Water Level on Foundation Settlement in Cohesionless Soil. The 18th International Conference on Soil Mechanics and Geotechnical Engineering, Paris, 2-6 September 2013, 216-229.

[4] Al-Ramthan, A.Q.O. (2012) Using Matlab with Quadrilateral Finite Elements in Analysis of Multi-Layered Nonhomogeneous Soils under Strip Footing. Research Journal of Applied Sciences, Engineering and Technology, 4, 717-723.

[5] Murthy, V.N.S. (2002) Geotechnical Engineering: Principles and Practices of Soil Mechanics and Foundation Engineering. Marcel Dekker Inc., New York.

[6] Das, B.M. (2015) Elastic Settlement of Shallow Foundations on Granular Soil: A Critical Review. http://gle.wisc.edu/wp-content/uploads/2013/07/Elastic-Settlement-Shallow-Foundations_A-Critical-Review-2.pdf.

[7] Smith, G.N. and Smith, I.G.N. (1998) Elements of Soil Mechanics. 7th Edition, Blackwell Science, Great Britain.

[8] Jassim, S.Z. and Goff, J.C. (2006) Geology of Iraq. 1st Edition, Published by Dolin, Prague and Moravian Museum, Brno, Printed in the Czech Republic.

[9] Al-Taie, E., Al-Ansari, N., Saaed, T.E. and Knutsson, S. (2014) Bearing Capacity Affecting the Design of Shallow Foundation in Various Regions of Iraq Using SAP200 \& SAFE Softwares. Journal of Earth Sciences and Geotechnical Engineering, 4, 35-52.

[10] Ail, S.M. (2012) Hydrogeological Environmental Assessment of Baghdad Area. PhD Thesis, College of Science, University of Baghdad, Baghdad.

[11] Al-Taie, E., Al-Ansari, N. and Knutson, S. (2014) Effect of Bearing Capacity on Designing Foundations in Iraq Using STAAD Pro-v8i. Engineering, 6, 292-303. http://dx.doi.org/10.4236/eng.2014.66033

[12] Al-Baidhany, A.H. and Albadran, B.N. (2005) Biofacies and Sedimentary Environments of Recent Sediments of Southern Part of Mesopotamian Plain. Journal of Basrah Researches (Sciences), 31, 13-20.

[13] Almutury, W.Gh. and Al-Asadi, M.M. (2008) Tectonostratigraphic History of Mesopotamian Passive Margin during Mesozoic and Cenozoic, South Iraq. Journal of Kirkuk University, 3, 31-50.

[14] Das, M.B. (2010) Principle of Geotechnical Engineering. 7th Edition, Cengage Learning, Stamford.

[15] Akpila, S.B. (2014) Bearing Capacity and Settlement Response of Raft Foundation on Sand Using Standard Penetration Test Method, SENRA Academic Publishers, British Columbia. Canadian Journal of Pure \& Applied Sciences, 8, 2769-2774.

[16] Brahma, P. and Mukherjee, S.P. (2010) A Realistic Way to Obtain Equivalent Young’s Modulus of Layered Soil. Indian Geotechnical Conference, GEOtredz, IGS Mumbai Chapter \& IIT Bombay, Mumbai, 16-18 December 2010, 305308.

[17] Bajad, S.P. and Sahu, R.B. (2012) An Experimental Investigation on Interference of piled Rafts in Soft Soil. Civil and Environmental Research Journal, 2, 49-59. www.iiste.org

[18] Ahmed, M., Mohamed, M.H., Mallick, J. and Hasan, M.A. (2014) 3D-Analysis of Soil-Foundation-Structure Interaction in Layered Soil. Open Journal of Civil Engineering, 4, 373-385. http://dx.doi.org/10.4236/ojce.2014.44032

[19] PLAXIS Version 2012.02 (2012) Material Manual, Delft University of Technology \& PLAXIS. The Netherlands, A. A. Balkema, Publishers. http://www.plaxis.nl/

[20] Das, B.M. (1999) Fundamentals of Geotechnical Engineering. Brooks/Cole, Pacific Grove.

[21] Ehsan, R. (2013) A Study of Geotechnical Constitutive Models Used in PLAXIS 2D. ICE G\&S Papers Competition. http://www.ice.org.uk/ICE_Web_Portal/media/southeast/Competitions/Raisa-Ehsan-past-paper.pdf 